UDC 930(477):274(477)“19/20"

DOI 10.24919/2519-058X.19.233808

\title{
Tetyana GRUSHEVA
}

PhD (History), Associate Professor at the Department of Modern Ukraine's History Zaporizhzhia National University, 66 Zhukovsky Street, Zaporizhzhia, Ukraine, postal code69600 (grushevaznu@ukr.net)

ORCID: 0000-0003-0560-8229

\section{Olha SPYS}

PhD (Philosophy), Associate Professor of the Department of Philosophy and History of Science and Technology State University of Infrastructure and Technologies, 9 Kyrylivska Street, Kyiv, Ukraine, postal code 04071 (olgaspys@gmail.com)

ORCID: 0000-0001-9439-8512

\section{Тетяна ГРУШЕВА}

кандидат історичних наук, доцент кафедри новітньої історії Украӥни Запорізького національного університету, вул. Жуковського, 66, м. Запоріжжя, Украӥна, 69600 (grushevaznu@ukr.net)

\section{Ольга СПИС}

кандидат філософських наук, дочент, дочент кафедри філософії та історії науки $i$ техніки Державного університету інфраструктури та технологій, вул. Кирилівська, 9, м. Київ, Україна, індекс 04071 (olgaspys@gmail.com)

Bibliographic Description of the Article: Grusheva, T. \& Spys, O. (2021). Reformation doctrine and political values: historical and philosophical analysis (on the example of late Protestantism in Ukraine). Skhidnoievropeiskyi Istorychnyi Visnyk [East European Historical Bulletin], 19, 204-216. doi: 10.24919/2519-058X.19.233808

\section{REFORMATION DOCTRINE AND POLITICAL VALUES: HISTORICAL AND PHILOSOPHICAL ANALYSIS (On the example of late protestantism in Ukraine)}

\begin{abstract}
The purpose the research is to determine the characteristics of political ethics in the reformation doctrine using the example of late Protestantism history in Ukraine. The research methodology is based on: general scientific methods (analytical, synthetic, paradigmatic, holistic), general historical (system chronological, historical and comparative), sociological method (content analysis). The scientific novelty consists in the fact that for the first time there has been made the attempt of a comprehensive analysis of the external factors influence on the political ethics of Protestants on the history example of the Protestantism in Ukraine during the 20th-beginning of the 21 st century in modern Ukrainian historiography and philosophical science. The Conclusions. The Reformation Doctrine was formed 500 years ago. It passed the test of time during this period. Having examined political ethics as a separate component of the doctrine, the authors of the article came to the conclusion that its key points were formed during the period of early Protestantism and have remained unchanged up to this day. Expressive specificity is the reaction to the historical conditions of existence and demonstration of
\end{abstract}


ethno-confessional differences. Genesis of Protestants in Soviet Ukraine is an example. Referring to the biblical thesis "All authority comes from God", the Protestants accepted all the slogans of the Soviet power. At their congresses, they even approved a military service. Afterwards the atheistic experiment in the Ukrainian SSR gained momentum and the representatives of theomachistic authorities resorted to repressions, in the society with a dominant hostile worldview believers tried to use various survival strategies starting with the insistent demands of communities registration ending with sit-in strikes and emigration attempts to "any non-socialist country". The Christians came to the conclusion that power from God also serves a good cause. The Protestants in modern Ukraine entered a political life slowly. Evangelical Christians most clearly demonstrate solidarity with public sentiments (participation in the Orange Revolution, the Revolution of Dignity, chaplaincy service). In the modern Protestant milieu, a blind submission to any authority is questioned therefore changes are made to pacifist sentiments and prerequisites for the formation of socio-political theology arise. Of particular values are the categories of truth, freedom and responsibility (which is the manifestation of ethno-confessional differences), and non-cult services are organized in compliance with orthodoxy and orthopraxy.

Key words: reformation doctrine, political ethics, late Protestantism, the Ukrainian Soviet Socialist Republic, modern Ukraine, orthodoxy, orthopraxy.

\title{
РЕФОРМАЦЙНА ДОКТРИНА І ПОЛІТИЧНІ ЦІННОСТІ: ІСТОРИКО-ФІЛОСОФСЬКИЙ АНАЛІЗ (на прикладі історії пізнього протестантизму в Україні)
}

\begin{abstract}
Анотація. Мета дослідження - на прикладі історії пізнього протестантизму в Україні визначити особливості політичної етики в реформаційній доктрині. Методологія дослідження спирасться на методи: загальнонаукові (аналітичний, синтетичний, парадигмальний, холістичний); загальноісторичні (системно-хронологічний, історико-порівняльний); та соиіологічний (контент-аналіз). Наукова новизна полягає у тому, що вперше в новітній українській історіографії $і$ філософській науці зроблена спроба комплексного аналізу впливу зовнішніх чинників на політичну етику протестантів на прикладі історії протестантизму в Україні XX-початку XXI cm. Висновки. Реформачійна доктрина була сформована 500 років тому. За чей період вона пройшла випробування часом. Дослідивши окрему складову доктрини політичну етику, автори статті дійшли висновку, щьо їі ключові тези були сформовані в період раннього протестантизму і залишаються незмінними до сьогодні. Виразні специфічності є реакиією на історичні умови існування та проявом етноконфесійних відмінностей. Прикладом слугує буття протестантів у радянській Украӥні. Посилаючись на біблійну тезу "всяка влада від Бога”, протестанти сприйняли всі гасла радянської влади. На своїх з'їздах вони висловили бажання навіть проходити службу в армії. Згодом, коли атеїстичний експеримент в УРСР набрав обертів і представники богоборчої влади вдалися до репресій, віруючі намагалися використати різні стратегії виживання в суспільстві з панівним ворожим світоглядом: від наполегливих вимог реєстраиії громад до оголомення сидячих страйків і намагання емігрувати в "будь-яку несочіалістичну країну". Так, християни дійшли висновку, що та влада від Бога, яка слугує добрій справі. Протестанти в сучасній Україні повільно включилися до політичного життя. Християни віри євангельської найбільш виразно демонструють солідарність із суспільними настроями (участь в Помаранчевій революиії, Револючії Гідності, капеланському служінні). У сучасному протестантському середовищі піддається сумніву сліпе підпорядкування будь-якій владі, вносяться зміни в пацифістські настрої, виникають передумови до зародження сочіально-політичного богослов'я. Особливою иінністю для нього є категорії правди, свободи i відповідальності (що є проявом етноконфесійних відмінностей), а позакультове служіння організоване із дотриманням ортодоксії та ортопраксії.
\end{abstract}

Ключові слова: реформачійна доктрина, політична етика, пізній протестантизм, Украйнська Радянська Соціалістична Республіка, сучасна Украйна, ортодоксія, ортопраксія.

The Problem Statement. The study of modern Ukrainian evangelical Protestants ethics is a topical objective for a comprehensive and systematic religious analysis in order to 
understand better the place and role of the Protestant Church in the formation of a civil society in Ukraine. The discussion of ethics issue cannot be considered in isolation from theology, because the latter determines the ethical norms that guide Christians of any denomination. Since the Ukrainian Protestants functioned in an atheistic totalitarian state for a long time -70 years, the developed eschatological theology could not but affect the formation of a passive mood for the society transformation. At the same time, this eschatological orientation made Protestants be very jealous of the ethical teachings, which permeate the entire New Testament. The evangelical Protestant environment has an impact on the society by its mentality, formed on the biblical and ethical categories of honesty, truthfulness, justice, conscientiousness in work, responsibility.

The Analysis of Recent Researches and Publications. The lack of researches on this issue is explained by the complexity of theoretical generalizations on the problem of the connection of political values and the Reformation doctrine of different historical periods in relation to global Protestantism. At the same time, during almost three decades of a religious freedom period in Ukraine, a number of works were published, which are of a fundamental importance for understanding the nature and directions of social and cultural changes in the evangelical environment of Ukraine. S. Sannikov, M. Cherenkov, R. Soloviy, M. Mokiyenko, V. Liubashchenko and Yu. Reshetnikov made a significant contribution to the study of various aspects of transformations in evangelical Protestantism. The processes that take place in the field of politics, education, social activities, military service are studied by V. Yelensky. The achievements and problems faced by the churches during the years of the Ukrainian state independence were analyzed in the works of P. Yarotsky and L. Filipovych comprehensively.

However, there are few separate works that focus on the Protestant ethics of evangelical Protestants in Ukraine. To this number of works one should include the monograph "Protestant Ethics and the Spirit of Ostmodernism" of M. Cherenkov, the Ukrainian theologian and philosopher, and V. Bachinin, the Russian sociologist. In the monograph the authors analyze the ethical challenges faced by evangelical Protestant churches in Russia and Ukraine.

A collective monograph written by 19 foreign and domestic scholars, politicians and pastors, edited by Roman Sheremet and Olha Romanenko, "The Reformation: Europe's Success and a Chance for Ukraine", highlights the impact of Reformation processes on Western Protestant ethics and possible influences on the formation of the Protestant ethics in Ukraine, the importance of which (ethics) is, in the opinion of the authors, significant and topical for the state-building processes and a successful development of social institutions.

In the article "Protestant Ethics in the Socio-Political Context of Ukraine: from Max Weber to Ukrainian realities" Konstantyn Teteriatnikov, a researcher, analyzing the work of M. Weber "Protestant Ethics and the Spirit of Capitalism", pays special attention to the issue: what needs to be done for the Protestant ethics to become an influential force for changing the society in the Ukrainian realities.

The article by H. Hololob, a theologian-apologist, "Was the Early Church Pacifist?" deals with the study of pacifism. The ethical problem of the relationship between the Church and the state is reflected in the article by V. Korenevych "The Relationship between the Christians and the State in the Light of the Commandment "do not kill". This problem, but from a different angle, is covered in another article - "Theology and Practice of Non-Violent Resistance of Martin Luther King", written by V. Zadorozhny.

The purpose of the study is to determine the peculiarities of political ethics in the Reformation Doctrine on the example of the history of late Protestantism in Ukraine. 
The Main Material Statement. In our opinion, ethical concepts that serve as identification markers of modern Protestantism, with all its specifics, passed the test of time: influenced by worldview paradigms of different historical epochs, and thus a certain transformation, the Protestant moral rules were formed in early modern times. Despite the generally accepted view in the scientific literature that the Protestants are the most dynamic religious movement, modernized in the spirit of the contemporary era, we have come to the conclusion that it is more correct to state that we follow the norms of the Protestant morality.

The article focuses on the evolution of political ethics in the Reformation Doctrine, which professed evangelical Protestantism in Ukraine in the XXth - at the beginning of the XXIst century; the influence of external factors on the Protestant ethical norms, the defense of the Christian values during the period of trial by atheistic ideology (on the example of the USSR); a socio-political activity of the Ukrainian Protestants during the Revolution of Dignity. Such a philosophical and historical digression determines the fundamental constants of the Protestant ethics.

The study of the late Protestants history in the Soviet totalitarian state with a dominant atheistic (hostile) worldview clearly demonstrates this. The "litmus test" is the believers' interpretation of the thesis "all power is from God", which will show the comparison of the Reformation doctrine and political values.

For the Ukrainian representatives of late Protestantism - mainly: Evangelical Christians-Baptists (ECB), Seventh-day Adventists (SDA), Evangelical Christians or Pentecostals (EC) - the time until the end of the 1920s is called "the Golden Decade": the state focused its militant steps on Orthodoxy, which embodied the former imperial system; the took advantage of the economic successes of the Protestant communities and started controlling the quantity of Baptists, Pentecostals and Adventists.

From 1924 to 1926, the Protestant churches organized congresses, assemblies, meetings, etc., at which they proclaimed the recognition of the Soviet power and oriented fellow believers to a peaceful existence in the state. Thus, in September of 1924, the First Provincial Meeting of Christians of the Evangelical Faith took place in Odesa. In the protocol of the meeting there was defined the need for a "sincere" attitude to the Soviet power, to support it "not because of fear, but in good conscience" (CSASBGAU, f. 5, c. 197, p. 49). At the 1st All-Union Congress of the Union of the Evangelical Faith Christians (1927) the need for loyalty to the new government was emphasized, otherwise believers would be "declared unworthy of the Christian title" (CSASBGAU, f. 5, d. 3, c. 1057, p. 25) (the directions of Evangelical Christians-Baptists and Evangelical Christians existed in the USSR separately until the end of the 1940s).

The Christians are known to defend the ideas of a religious pacifism, they do not take up arms and refuse to take an oath. Thus, the Ukrainian Baptist churches were formed under the influence of Anabaptists, who kept to the principles of pacifism, that is why, this position is quite strong for many Ukrainian Baptists. Since 1926, the law "On Compulsory Military Service" had been extended in the USSR. In the law there were specifically addressed requirements for the believing part of the population regarding the army service, in particular, - a compulsory military service could be replaced by other duties: in peacetime it was a community service, in wartime - the work in teams to provide service to the rear (CSASBGAU, f. 5, d. 3, c. 1053, pp. 86-87; SAZR, f. 324, d. 1, c. 202, p. 121). The state controlling authorities noted that the representatives of the CEB, the SDA and some others recognized the conscription as necessary (CSASBGAU, f. 5, d. 3, c. 1053, p. 31). Thus, there 
was no conflict between the Protestants and the authorities over their refusal to serve in the army during the 1920 s.

Since the end of the 1920s, the situation in Soviet Ukraine had become more complicated for the Protestant believers: preaching had been the subject to a comprehensive control (it was a direct interference in the internal life of religious communities), prayer houses were closed en masse, a wave of arrests of religious cults begans. This is how the atheistic experiment gained momentum.

After the end of World War II, believers experienced all the cruelty of the regime. Some of them were accused of refusing to mobilize and collaborating with the Nazi authorities. Lawsuits against "traitors to the Fatherland" were used by Soviet ideologues for atheistic purposes: for a long time in literature and the press, mentioning the Protestants, the authors pointed at the "pro-fascist sentiments of sectarians". Thus, the broad sections of the population were instilled with an artificially distorted image of the believer: the "illiterate, secret buzuvir", who, by virtue of its existence, did harm to the Soviet state.

Gradually, the totalitarian state determined the religious denominations, which were granted permission to exist (to register). Accordingly, some believers were outlawed and entered the so-called religious underground. Such religious groups, being in the field of view of the commissioners of the Council for Religious Cults under CM of the USSR in UkrSSR, were not the object of study, the materials on them were transferred to the state security authorities (CSAPAU, f. 1, d. 24, c. 12, p. 206). At the beginning of the 1960s, the Council identified 25 cults that were not the subject to registration, including: Pentecostals, Adventists-reformists, Pure Baptists, Evangelical Christians, Pentecostal Sabbaths, etc. (CSAPAU, f. 1, d. 24, c. 5488, p. 18).

It is noteworthy that the supervisory authorities even identified a "common denominator" of the religious underground. The most dangerous features were considered: refusal to participate in a public life of the country, refusal to attend cultural and educational institutions, refusal to ask for a medical help, refusal to participate in elections, refusal to join collective farms. Such allegations can be confidently refuted to the majority of Protestants, who tried to adapt to the current conditions. The severity of governmental decisions was related to the totalitarian state's attempt to establish control over all spheres of life and to overcome an alternative worldview.

Believers not only of forbidden cults, but also of those permitted by law, were deprived of the opportunity to perform religious rites. This position of the church was interpreted by the governing bodies as "establishing a real control" over the activities of religious associations. The atheist state resorted to artificial measures to unite related cults (in 1945 - Pentecostals with the Union of Evangelical Christians-Baptists, whose alliance proved to be completely unviable). The activities of the Evangelical Christian-Baptists Church were strictly controlled and regulated by government agencies; the Christian-Baptists were extremely limited in making independent decisions. This led to the situation when disobedient communities formed an alternative church with a governing body, the Council of Churches of the ECB (1965). After vain demands for establishing a government commission to persecute the faith in the USSR, the leaders of such nonconformist communities were repressed.

Step by step, the opposition "the atheist state - the Protestants" took chronic forms and lasted for the entire Soviet period.

During the 1960s, unregistered Protestant communities continued to try to legalize activities, Pentecostals and schismatic Baptists even petitioned the government and the 
Central Committee of the CPSU. At the same time, there appeared the first claims for radical methods of struggle (hunger strikes and sit-ins) to meet the demands (CSAPAU, f. 1, d. 24, c. 5991, p. 195). Thus, there came the time for reaction of Protestants, who found themselves on the brink of extinction, and the Christian thesis of "all authority comes from God" needed to be commented.

The Secret Congress of Evangelical Christians (in 1948, Dniprodzerzhynsk) became a counterweight to the All-Union Council of Evangelical Christians-Baptists. The "Dogmas of Christian Belief of Evangelists" were approved, which were a response to the state's refusal to register it. It was stated in the Dogmas that relations with the Soviet state and public organizations were impossible. Such decision was perceived by the governing bodies of the state as "anti-Soviet"; as a result, members of the asset were repressed. The next step - the organization and holding of the Fraternal Assembly (in 1956, Kharkiv) (the state bodies declared this meeting an illegal congress). The participants of the meeting approved new provisions concerning the attitude to the Soviet legislation: general military service, the prohibition of believers to bring up children in a religious spirit and other requirements of the state were declared, which were contrary to the Word of God (SADR, f. 6463, d. 2, c. 20, pp. 74-78).

The organizational work of Protestant leaders, on the one hand, contributed to a special intensification of missionary work in the second half of 1956 and at the beginning of 1957, which was a direct disobedience to the state. On the other hand, - in contrast to the state measures, isolationist tendencies intensified in the Protestants environment (prayer meetings were held in absentia), participation in the public life of the country was more and more often declared a "sinful deed". The content of the sermons guided the believers to abandon cultural and educational institutions, listening to the Soviet radio programmes, reading fiction (Archival Subdivision of the USBU in Zaporizhia Region, c. p-13278, vol. 1, p. 55).

Another step of disobedience to the state in order to meet the religious needs of the Soviet believers was the attempt to establish contacts between fellow believers from abroad. Religious literature appeared in the UkrSSR illegally; believers tried to join listening to radio programmes broadcast from abroad ("Bible Lectures" (the USA), "Echoes of Youth" (Canada), etc.). Those activities violated the state regulations. To isolate the Soviet believers from the world religious movements, the Central Committee of the Communist Party of the UkrSSR adopted a resolution "On Intensification of the Struggle against Foreign Religious Propaganda" (1977). The Soviet researchers, analyzing religious radio broadcasts, accused foreign Protestant centers of anti-communism, "psychological diversion" and even the existence of a "religious opposition" to socialism (Rotovskii, 1988, pp. 164-168).

Since the end of the 1970s, analyzing the situation in the Protestant community, the term "religious extremism" had been increasingly used by the authorities. Illegal actions included: refusal of believers to participate in elections, calls to pray for "prisoners of conscience", organized religious education for children, refusal of conscripts from Protestant families to take the military oath. Believers of illegal Pentecostal groups, supporters of "the Council of Churches of the ECB", also protested against the communist upbringing of youth and atheist propaganda, demanding recognition of the right to "conduct not only atheistic but also religious propaganda" (CSAPAU, f. 2, d. 14, c. 1726, p. 19).

Totalitarian methods of combating religion turned religious communities into reservations. Thus the point of no return had been passed, the Protestants moved to the next level of resistance. In the 1980s, the CBE underground episcopate declared registration a "blatant violation of the Word of God"; the decision in this regard stated that the state laws should be 
obeyed only when they serve "good glory and for the Lord" (CSAPAU, f. 1, d. 25, c. 2403, p. 37). d Such sentiments indicate an obvious fiasco of the atheistic ideology in counteracting the religiosity of the population. Thus, in 1970 - 80 researchers at the Center for the Study of Religion and Communism (Keston Institute), studying the problem of the survival of religion under the conditions of its suppression by the communist leadership, used the terms: "catacomb churches", "religious protest", "religious renaissance" rightly.

We believe that during the 1970s such protest took the form of both covert and open confrontation. For example, in the Pentecostal environment during this period, dissatisfaction with the active process of atheism of the population manifested itself in the emergence of emigration sentiments (in the USSR, this process began in 1977), that took an organized form (CSAPAU, f. 1, d. 25, c. 1508, pp. 4, 47). Believers stated that they were "prisoners of the Soviet government", which did not comply with international agreements. The punitive authorities, in response to such disobedience of believers, used the infamous methods of "mental violence" (when dissenters were forcibly taken to psychiatric hospitals). Dnipropetrovsk Protestants openly reported to the International Committee of the Red Cross, the World Health Organization and other international organizations in the document "Facts and Only Facts". The fight against dissent in Soviet Ukraine was described in detail by them in the "Request for Help Statement" addressed to the UN Human Rights Committee, to the heads of 35 states, who signed the Final Act of the Helsinki Agreement. An "Open Letter" was also prepared and sent to the President of the United States; statements of "Requests for Help" sent to the US political organizations (SADR, f. 6465, d. 2, c. 26, pp. 67-85).

The leaders of the Pentecostal movement sent the statement to the Central Committee of the CPSU, the United Nations, and the International Association of Democratic Lawyers, emphasizing the lack of constitutional freedoms, the ban on prayer meetings and imprisonment for faith. The statement emphasized the requirement to allow believers to leave the USSR freely (SADR, f. 6465, d. 2, c. 37, p. 219). Biographical references of believers, persecuted in Soviet Ukraine, were sent abroad (CSAPAU, f. 1, d. 25, c. 2403, pp. 37-38). At the end of the 1970s, the Baptists joined the wave of emigration, and some of them made categorical demands: if they were not allowed to leave the USSR, they would demand renunciation of the Soviet citizenship (CSAPAU, f. 1, d. 25, c. 1887, p. 32).

The totalitarian state reacted to such steps by repressions. This, in turn, did not stop the Protestants: emigration sentiment remained unchanged during the 1980s. In 1987, a new wave of emigration among believers arose. In order to help them leave the country in an organized way, they created an "initiative group - the Christians for leaving the USSR" (CSAPAU, f. 1, d. 25, c. 3329, p. 24).

Thus, the period of the existence of the Protestants in atheistic Soviet Ukraine was the period of trial: the Protestants recognized the Soviet power during the 1920s, tried to legalize their activities during the prewar and postwar period; feeling the flywheel of repression, they went underground; having lost hope of being able to profess the faith, they became the opposition to the existing system (went on hunger strike, tried to emigrate to a "non-socialist country", sent letters to international organizations in order to tell the truth about the life of believers in an atheistic country).

The period of Ukraine's independence was the time of free Protestant service renewal. It is noteworthy that during this period the universal values of the Protestants, which were formed during the Reformation, were clearly manifested: the national consciousness manifestations, the absence of dogmatic restrictions on human thought, intellectual culture, spiritual freedom, 
autonomy of the individual, individualism, anthropocentric norms, the concept of autonomy of a secular and spiritual rule. At the same time, the strategic goal of the Protestants of that period and modern Protestants is called "the improvement of Christianity". These ethical norms are the bridge between early and modern Protestantism, as well as a common denominator for various Protestant denominations. At the same time, it is necessary to note the peculiarities in ethics, which time imposed (modernization processes, persecution of believers during the Soviet period), and ethnic specifics. Let us consider the following peculiarities in detail on the example of non-religious activities of modern Ukrainian Protestants.

The age-old desire for freedom of the Protestants found expression in gaining freedom in independent Ukraine largely. In this context, it should be noted that Ukraine has conditions for different types of freedoms; the Protestants are "not drawn" into the orbit of the political game. On the one hand, they are not focused on political circles, on the other hand, - they have no preferences in power. Therefore, freedom and truth are the two ethical categories which, as recent events over the past five years have shown, are the key principles in the ethics of the Ukrainian Protestants.

The Revolution of Dignity of 2014 was one of the best expressions of the Protestant ethics of the Ukrainian Protestants. The Maidan became the time and space where orthodoxy intertwined with orthopraxia for the Protestants. The Protestant Church performed several missions on the Maidan. The mission of preaching was one of the most important missions seen by the Protestant churches. The Protestants, as "people of the Book", were seriously motivated to convey the idea of a God-reborn man. Awareness of the issues that without the change of worldview, without reconciliation with God, it is impossible to begin to build a truly free and prosperous country, motivated the Protestants to preach the Gospel, especially at the time when the society, being in a high tension, was waiting for changes. The holistic approach on which the evangelical Protestant worldview is based must have the right sequence, the violation of which will not lead to any results. The primary thing for Evangelical Protestants is always the reformation of a man, which consists in the liberation from the cause of all that hinders healthy spiritual development. And only the change of people, according to Evangelical Protestants, will change the political, economic, tax, environmental systems and everything.

At the end of the 1990s, the Protestant activity in the country's political life increased markedly. The year of 2004 was a landmark year for the Ukrainian society. Historians and philosophers emphasized that at that time the most expressive solidarity with the public mood was shown by the Christians of the Evangelical Faith, Evangelical Christians-Baptists were much more cautious, and Seventh-day Adventists remained distanced from the public slogans. The Revolution of Dignity and the Russian-Ukrainian war became a powerful lever of influence on the worldview of the Ukrainian Christians, who spoke with slogans of freedom and justice against the current system at the Maidan. For the Ukrainian society, the Maidan "resurrected" many moral themes, for which the Protestants were well prepared throughout their history and living practicing faith. It should be noted that the specified moods of the Christians of the Evangelical Faith, Evangelical Christians-Baptists and Seventh-day Adventists preserved their features during the revolution of 2004 and the Revolution of Dignity. The focus on success, which is a Protestant business card, became a motivating lever to support the revolutionary slogans for Ukraine's movement by the model of developed democracies. The active involvement of the faithful into the chaplaincy service demonstrated the desire to defend the country clearly. 
For the Protestant ethics, responsibility, truth, conscience, were always a high virtue in both family and public life. Therefore, various manifestations of imitation in the society justice, democracy, education, manipulation of consciousness by means of the media make the Ukrainian Protestants "join" a social activity as disagreement with untruth. The presence of all these virtues testifies to the vitality of the Church, its conformity to evangelical ideals.

The category of truth became a special value to the Ukrainian Protestants during the Revolution of Dignity. The very defense of the truth was one of the main motives for the participation of the Protestant Church at the Maidan. At the present stage, the Ukrainian Evangelical Protestantism is becoming a unique phenomenon in comparison with Western and Russian Protestantism. According to Bishop M. Panochko, the head of the Union of the Christians of Evangelical Faith, - "Western Protestantism lost its power precisely because it lost its truth. The property of the Church is to influence. To influence, you must have the truth. The church is strong when it is true" (Spys, 2020). Other Protestant leaders share the same view. V. Antoniuk, the head of Eastern Church of Evangelical Christians-Baptists said: "The power of the church - always to be on the side of truth, regardless of government" (Antoniuk, 2014). H Komendant, a former head of Eastern Church of Evangelical ChristiansBaptists, a head of the Bible Society, said: "We must be salt to the world around us, a reminder of the truth" (Komendant, 2014, p. 119).

M. Panochko defined the events that took place in the Ukrainian society during the Revolution of Dignity, first of all, as a spiritual struggle. "Devaluation of the truth, - the senior bishop of the Church of Christians of Evangelical Faith of Ukraine emphasized, became the reason for a fake society emergence" (Spys, 2020).

Freedom has always been a special value to the Ukrainian Protestants. The desire for various kinds of freedom, including freedom from Russia, from an unjust corrupt government, from the ideological legacy of the USSR, was too important for the Ukrainian Protestants after a long period of persecution. However, the unifying force at the Maidan for the Protestants was not only freedom "from", but also freedom "for". It was freedom "for" that became a good foundation for the large-scale celebration of the 500th anniversary of the Reformation, during which Evangelical Protestants declared themselves as the united Protestant Church, remaining multi-religious at the same time. The celebration of the " $\mathrm{R}-500$ ", when the Protestants not only talked about achievements but also reflected on the history lessons and revised their activity, coincided with the post-Maidan times, still full of faith in building a new, truly independent state. Freedom "for" set new tasks - to reformat thinking from local to global - to go beyond the boundaries where your church is, to a wider space - the state. In other words, to engage with the society as a whole, not just the part of it.

Freedom and responsibility are the ethical categories through the prism of which the Ukrainian Protestants reconsider their future ministry. The new political situation, which arose in the Ukrainian society in $2014-2015$, is also imposed with the challenges of a contradictory postmodern world with various crises - political, economic and environmental. The categories of freedom "for" and responsibility require joint projects and ways to implement them, which one church is unable to do. These factors create the need to form a number of theologies that will certainly make adjustments to the Protestant ethics in Ukraine.

The Jubilee Year of the Reformation, the loyalty of the authorities, and the expectations of the Ukrainians for change after the Revolution of Dignity enabled the Ukrainian Protestants to try to influence the birth of a new Ukrainian society by bringing the Protestant ethics into various spheres. This is evidenced by the numerous activities that were carried out, involving 
to some extent various public institutions - city councils, universities, libraries and deputies. It was in the year of " $\mathrm{R}-500$ " that the Protestants attracted attention and invited well-known public figures, parliamentarians, professors, and preachers from the Western world to our country in order to acquaint various social institutions with the Reformation ideas on which the Protestant ethics was formed. The idea of acquainting the Ukrainian social institutions with the success of Western society, formed on the basis of the ethics of the Protestants, is fully illustrated by the collective monograph: "Reformation: Europe's Success and a Chance for Ukraine". The monograph is written by 19 foreign and Ukrainian authors. The monograph is a kind of attempt of the Ukrainian Protestant elite to push the Protestant community to the importance of developing a public theology. The authors of the monograph emphasize those Biblical principles, the introduction of which is necessary for changes in various spheres of the Ukrainian society: the institution of the state formation, economic, legal system, the institution of family, the medical field. One of the key principles that the Ukrainians must learn are: the rule of God's law, the priority of the value of the individual as a personality, the establishment of a clear limit of government interference in people's lives, the introduction of professional ethics, which consists in the thesis: "one should serve (not rule) his people first and foremost with love" (such theses sound consonant with the early Protestant ones).

Numerous discussions of theologians, leaders of various parachurch organizations and the position of pastors of the Ukrainian Protestant community at conferences, on the Internet and at Sunday services sermons - M. Cherenkov, R. Soloviy, S. Sannikov, Ya. Lukasik, V. Bozechko, K. Teteriatnikov, H. Komendant, A. Kaliuzhny, D. Horenkov, M. Panochko, V. Antoniuk, M. Romaniuk and many others indicate that nowadays the Protestant Church in Ukraine, perhaps not fully aware, more intuitively, joined the formation of a public theology, which would pay more attention to the relationship between the Church and the society. Until nowadays, the absence of a public theology could not form a number of positions in the ethics of the Ukrainian Protestants. This factor makes the Ukrainian Protestant ethics very different from Western Protestant ethics. Public theology involves considering issues that are quite controversial in the Evangelical Protestant environment due to various factors - the formation of communities or entire unions by different traditions (for example, Calvinist and Arminian in Baptism), which formed, respectively, a different view on many issues. Such issue is the pacifist question of the Church's participation in a political life (this question is seriously influenced by historical factors - the faithful of the "new" Baptist or Pentecostal communities, who are free from fear of persecution, sincerely believe that the Church must not only have a dialogue with politicians, but also be among them and influence actively; unregistered communities, on the contrary, take a position of distance from politics; personal - for example, "old" communities, led by a young pastor whose theological education was influenced by Western theology, may have a moderate attitude toward the Church's involvement in politics; regional factors (communities from Western Ukraine with a clear national position are more active in a political life than communities from the south of Ukraine).

However, the formation of a public theology in the Protestant environment is very slow due to the lack of a clear understanding of how the Church, interacting with the society, should not merge with it, but rather be a voice of conscience for the society, a pillar and affirmation of truth. The vast majority of the Protestants have fear - how to serve the society not to become a servant. Evangelical Protestantism in Ukraine, although not a direct descendant of the European Reformation, sees its roots in the European Reformation. 
The fear, of course, that hinders the development of new methods and forms of cooperation with the society cannot be seen as a positive phenomenon, but the slogan of the Reformation "The Unchanging Gospel to the Changing World," which was announced by S. Sannikov, a leading and extremely authoritative theologian in the Ukrainian Protestant community, in the year of the 500th anniversary of the Reformation, is an expression of the worldview and, at the same time, the definition of the vector of a large cohort of believers of the Evangelical Protestant movement in Ukraine (Sannikov, 2015, p. 216).

It is worth emphasizing that for the first time in the history of functioning in Ukraine during the Revolution of Dignity, the Protestants felt the attitude to themselves as full-fledged equal citizens. This certainly raised their faith in Ukraine as a homeland where their orthodoxy and orthopraxia would be in demand. Awareness of the revision of socio-political thinkingfrom nihilism in relation to the world - to an active position in the socio-political life of the country, raised the question: "Is there any authority from God?" If not, how should Christians behave? In other words, in the Ukrainian Protestant environment there are preconditions for the emergence of socio-political theology.

The state when the socio-political consciousness of Christian Protestants was "unlocked from the biblical energy system", the Ukrainian Protestant theologian, Doctor of Philosophy Mykhailo Cherenkov, defined as degradation for the Protestants (Cherenkov, 2015, p. 154). Why did this happen? M. Cherenkov draws an important conclusion that the thesis "there is no power but God's power" explains the principle of a hierarchical subordination, which was established by the Creator to maintain order in the worlds (both spiritual and social, and natural). But not every person in power follows spiritual norms. If there are many such violations, then "distorted political systems-deviants" may arise, where the government becomes a God-fighting weapon. From such power "comes nothing but evil. So the Christians have no reason to claim that this kind of power is from God" (Cherenkov, 2015, pp. 147-148). At the same time, there are still many fears of the communist totalitarian era in the Ukrainian Protestant community. This sometimes results in a blind obedience to any authority that the Protestants inherited since the Soviet period, particularly in the postwar Soviet period, when, as the Ukrainian researcher O. Panych writes, the state and power became symbolic images of the "other" in the evangelical religious worldview of Christians-Baptists" (Panych, 2016, p. 58). However, this state creates a dichotomy for the Protestants with their freedom-loving nature. At present, a number of theological works, numerous statements in interviews with the Protestant leadership, show that the difficult intertwining of the categories of truth, freedom and responsibility is no longer so complex and confusing. Bishops, teachers, and theologians instill in believers an understanding that the Christians are exempt from the moral obligation to obey the state when biblical laws are distorted.

According to many authoritative Protestant ministers, the Church cannot stand aside from the political life of the country, as it cannot but react to untruth. The great temptation in the ethical plane of the modern church is to allow oneself to be manipulated. V. Boechko, bishop of the Church of Christians of the Evangelical Faith, is convinced that the First Apostolic Church was also involved in politics when it was persecuted by the authorities, but the church did not compromise with the authorities. "It was resistance. It was politics", - said the bishop (Boiechko, 2014, p. 49).

The pastor of the New Life Baptist Church, A. Kaliuzhny, in an interview, expressed the position of many Protestants as follows: "If the people do not like the state steps, then it is "criminal to remain silent", we need to talk about it "whatever it costs us" (Kaliuzhnyi, 2014, p. 641). 
Modern Ukrainian researcher H. Trehub notes that such a cohort of Protestants was formed, "who are the part of a civil society and a new Ukrainian political nation" (Trehub, 2017, p. 121). However, it is difficult to determine the percentage of those Protestants who are neutral in the society, including politics, and those who are active. But content analysis of the Protestant media, materials from the Internet resources reveal that the Protestants, who believe that the theology of apoliticalness is a theology of fear, are more and more numerous.

The Revolution of Dignity and the modern Russian-Ukrainian war forced the Protestants to return to rethinking the issue of the relationship between a Christian and the state in the light of the commandment "do not kill". Analysis of the Bible books through the prism of this issue - Deuteronomy and Romans, secular law (Articles 115 and 36 of the Criminal Code of Ukraine, Art. 97 of the Charter of the garrison and guard services of the Armed Forces of Ukraine, etc.), some works of European Protestants (Henri Didon, Ulrich Eckmann, Richard Hayes) give the Ukrainian theologians reason to change the pacifist sentiments of the Protestant environment. Such changes are based on the conclusion that the commandment "do not kill" applies only to those who are motivated by a personal malicious decision - to take a person's life or commit it through negligence. Such murder is called criminal. Other murders, during which the actions of one person threaten the life of another person to prevent a serious crime currently committed by the latter, are not criminal (Korenevich, 2014, pp. 111-112). Thus, step by step, the Ukrainian Protestants overcame the isolationist position and apoliticalness that were artificially formed during the totalitarian era. Nowadays they are an important ethno-confessional segment of the society with clearly defined ethical rules.

The Conclusions. With the emergence of Protestantism, clear worldview ideas and ethical norms of this religious trend are formed, which will become the leading ones for the next centuries. The historical path, ethno-confessional specificity add differences without changing the fundamental Protestant principles. Proof of this fact is the history of Protestantism in Ukraine. After conducting a historical and philosophical analysis of the Reformation Doctrine and political values on the example of the history of late Protestantism in Ukraine, we concluded that dominant in the worldview of the Protestants are universal Christian values, such as: spiritual freedom, anthropocentrism, intellectual culture, etc. They remain unchanged for centuries, despite political realities. At the same time, the biblical instruction "Let every man be subject to the highest authority: for there is no authority but God and those existing powers are established by God" is interpreted by believers, based on the understanding that the state laws should be obeyed only when they serve "Good glory and for the Lord". This is clearly demonstrated by the history of late Protestantism in the UkrSSR.

Democratic processes and recent events in Ukraine (the Revolution of Dignity, modern Russian-Ukrainian war) gave impetus to the actualization of some principles of ethical teaching, namely: the relationship between a Christian and the state, a Christian and the society, a Christian and politics. An important task in the context of democracy and freedom for the ethics of modern Evangelical Protestants is to understand the vocation, which can be a serious lever of influence on the Ukrainian society. All this requires the creation of a number of theologies - public, political theology, labour theology, education, which have not yet been formed in the Ukrainian Evangelical Protestant theology for objective and subjective reasons.

Prospects for Further Research. Historical and philosophical analysis of the Reformation doctrine can be carried out on the basis of a comprehensive study of various ethical aspects, taking into account the ethno-confessional specifics of European Protestantism, with the involvement of sources of a foreign origin. 
Acknowledgement. The authors of the article are sincerely grateful to all members of the editorial board for the advice provided during doing the research and writing the article.

Financing. The authors did not receive any financial support for doing the research and writing the article.

\section{BIBLIOGRAPHY}

Antoniuk, V. (2014). Yakshcho narod hovoryt pravdu, shukaie spravedlyvosti, bazhaie pozbutysia koruptsii, zhyty chesno - Tserkva musyt pidtrymaty [If the people speak the truth, seek justice, want to get rid of corruption, live honestly - the Church must support it]. URL : https://www.religion.in.ua/ zmi/ukrainian_zmi/26378-valerij-antonyuk-yakshho-narod-govorit-pravdu-shukaye-spravedlvostibazhaye-pozbavitisya-korupciyi-zhiti-chesno-cerkva-musit-ce-pidtri [in Ukrainian]

Arkhivnyi pidrozdil USBU v Zaporizkii oblasti [Archival Subdivision of the USBU in Zaporizhia Region].

Boiechko, V. (2014). Yevromaidan, yak lakmusovyi papirets, pokazuie, khto my ye [Euromaidan, Like a Litmus Test, Shows who we Are]. In. L. O. Fylypovych, O. V. Gorkusha (Ed.). Maidan i Tserkva. Khronika podii ta ekspertna otsinka (pp. 49-52). Kyiv : Sammit-Knyha. [in Ukrainian]

Cherenkov, M. (2014). Yakshcho Tserkva ne bula na Maidani, to Maidan bude u Tserkvi [If the Church was not at the Maidan, the Maidan will be in the Church]. In. L. O. Fylypovych, O. V. Gorkusha (Ed.). Maidan i Tserkva. Khronika podii ta ekspertna otsinka (pp. 93-94). Kyiv : Sammit-Knyha. [in Ukrainian]

Derzhavnyi arkhiv Dnipropetrovskoi oblasti [State Archives of Dnipropetrovsk Region-SADR]

Derzhavnyi arkhiv Zaporizkoi oblasti [State Archives of Zaporizhia Region - SAZR]

Kaliuzhnyi, A. (2014). Nam nuzhno kajat'sia, chto ne sohranili mir [We Need to Repent that we did not Keep the Peace]. In. L. O. Fylypovych, O. V. Gorkusha (Ed.). Maidan i Tserkva. Khronika podii ta ekspertna otsinka (pp. 640-646). Kyiv: Sammit-Knyha. [in Russian]

Komendant, H. (2014). Sohodni Ukraina na mezhi bankrutstva, i tse znak dlia Tserkvy - usvidomyty svoiu vidpovidalnist za tse [Nowadays Ukraine at the Time of Bankruptcy, and a Sign for the Church - to Understand its own Resposibility for it]. In. L. O. Fylypovych, O. V. Gorkusha (Ed.). Maidan i Tserkva. Khronika podii ta ekspertna otsinka (pp. 116-120). Kyiv: Sammit-Knyha.[in Ukrainian].

Korenevich, V. (2014). Vzaimootnosheniya hristianina i gosudarstva v svete zapovedi "ne ubej" [The Relationship between a Christian and the state in the Light of the Commandment "Do not Kill"]. Bogomyslie, 15, 105-122. [in Russian]

Panych, O. (2016). Instytualizatsiia yevanhelskoho protestantyzmu v Ukraini (1990-ti 2000-ni roky) [Institutionalization of Evangelical Protestantism in Ukraine (the 1990s - the 2000s)]. Ukrainske relihiieznavstvo, 77, 55-66. doi: https://doi.org/10.32420/2016.77.634 [in Ukrainian]

Rotovskii, A. A. (1988). Klerikalnaia propaganda tseli i sredstva [Clerical Propaganda: Goals and Means]. Kharkov: Prapor, 235 p. [in Russian]

Sannikov, S. (2015). Implementatsiia Semper Reformanda vo vremennykh i kulturnykh kontekstakh Vostochnoi i Zapadnoi Evropy [Implementation of Semper Reformanda in the Temporal and Cultural Contexts of Eastern and Western Europe]. Bogoslovskije razmyshlenija. Reformatsija: istorija i sovremennost'. Spetsial'nyj vypusk, 9-25. [in Russian]

Spys, O. (2020). Interviu z M. Panochkom [Interview with M. Panochko]. (Arkhiv avtora). [in Ukrainian]

Trehub, A. A. (2017). "Chytaty znaky chasu": vitchyzniana baptystska teolohiia u svitli vplyviv suspilnykh transformatsii v Ukraini ta rosiisko-ukrainskoi viiny ["To Read the Signs of the Time": Domestic Baptist Theology in the Light of the Influences of Social Transformations in Ukraine and the RussianUkrainian War]. Ukrainske relihiieznavstvo, 84, 116-125. doi:10.32420/2017.84.799 [in Ukrainian]

Tsentralnyi derzhavnyi arkhiv hromadskykh obiednan Ukrainy [Central State Archive of Public Associations of Ukraine-CSAPAU]

Tsentralnyi derzhavnyi arkhiv vyshchykh orhaniv vlady ta upravlinnia Ukrainy [Central State Archive of the Supreme Bodies of Government and Administration of Ukraine-CSASBGAU]

The article was received on May 07, 2021. Article recommended for publishing 19/05/2021. 